\title{
PENGGUNAAN KARYA SENI MURAL DI PEMANDIAN AIR BARAT DESA RANGGUNG SEBAGAI MEDIA PENDUKUNG BERBASIS EDUKASI SOSIAL KEMASYARAKATAN
}

\author{
Vika Martahayu1), Rahmat Irfansyah ${ }^{1)}$, Aan Anharudin ${ }^{1)}$ \\ ${ }^{1)}$ Program Studi Pendidikan Guru Sekolah Dasar, STKIP Muhammadiyah Bangka Belitung, Pangkal Pinang, Indonesia \\ Corresponding author : Vika Martahayu \\ E-mail: vika.martahayu@stkipmbb.ac.id
}

Diterima 3 Maret 2020, Disetujui 5 April 2020

\begin{abstract}
ABSTRAK
Pembuatan artikel ini bertujuan untuk memberikan edukasi bagi masyarakat dan sebagai bahan referensi dan rujukan bagi desa serta instansi lainnya. Metode pelaksanaan yang digunakan oleh mahasiswa KKN di desa Ranggung melalui berbagai tahapan dan terbagi menjadi beberapa tahap seperti, tahap persiapan, tahap pelaksanaan dan tahap penyelesaian. Pada tahap persiapan mahasiswa melakukan observasi lapangan selama 2 hari yaitu pada hari Rabu dan Kamis pada Tanggal 29-30 Januari 2020, pada tahap pelaksanaan mahasiswa melakukan selama 5 hari terhitung dari tanggal 31 Januari sampai dengan 04 Februari 2020, sedangkan pada tahap penyelesaian dilakukan selama 1 hari pada tanggal 05 Februari 2020. Program KKN di Desa Ranggung adalah salah satu bentuk pengabdian dari mahasiswa untuk masyarakat dari program yang telah dilaksanakan salah satunya pembuatan mural di Air Barat yang bertujuan untuk memberikan pesan moral kepada masyarakat meliputi nilai keagamaan, nilai sosial, dan nilai budaya.
\end{abstract}

Kata kunci : seni mural; edukasi.

ABSTRACT
The making of this article aims to provide education for the community and as a reference for villages and other agencies. The implementation method used by KKN students in the Ranggung village through various stages and is divided into several stages such as, the preparatory stage, the implementation stage and the completion stage. In the preparation stage students conduct field observations for 2 days, on Wednesday and Thursday 29-30 January 2020, at the implementation stage, students conduct 5 days from 31 January to 4 February 2020, whereas the completion stage was carried out for one day on 5 february 2020.The program KKN in the Ranggung village is a form of community service for the community from the program that has been carried out, one of which is the creation of murals in Air Barat which aims to provide a moral message to the community including religious values, social values and cultural values.

Keywords : murals art; education.

\section{PENDAHULUAN}

Desa ranggung merupakan sebuah desa yang terletak di kecamatan payung kabupaten Bangka Selatan. Seperti halnya desa pada umunya, desa Ranggung merupakan desa berkembang yang sedang giat-giatnya membangun fasilitas untuk menuju desa wisata di kecamatan Payung. Untuk saat ini, desa Ranggung sedang gencar melakukan kegiatan pemberdayaan masyarakat dengan menfaatkan fasilitas yang ada, seperti tempat pemandian air barat yang terletak di Dusun 1 RT 12.

Tempat pemandian air barat awalnya merupakan sumber pemandian utama masyarakat sekitar. Namun seiring berjalannya waktu, pemandian tersebut dikembangkan dan direnovasi oleh pemerintah desa untuk menjadi objek wisata agar menjadi daya tarik masyarakat baik masyarakat lokal maupun luar daerah untuk datang ke Desa Ranggung. Selain itu, untuk menarik perhatian sekaligus memberikan edukasi kepada masyarakat lokal maupun luar daerah kami dari tim KKN STKIP Muhammadiyah Bangka Belitung berinisiatif untuk membuat karya seni Mural.

Masyarakat di Desa Ranggung memanfaatkan pemandian AirBaratsebagai sumber air dalam kehidupan sehari-hari. Tidak hanya itu, tempat pemandian ini juga dimanfaatkan sebagai tempat mencuci pakaian dan mandi. Bagi anak-anak Desa Ranggung, Air Barat dijadikan sebagai tempat bermain dan berenang. Selain itu pemandian Air Barat juga 
digunakan untuk berlatih berenang bagi siswa Sekolah Dasar yang berada di Desa Ranggung. Menurut Didit, dkk (2017: 483) Mural adalah menggambar atau melukis diatas media dinding yang relatif luas. Tujuan mural tentunya tergantung pada orang-orang atau pihak-pihak yang berkepentingan. Sedangkan Susanto dalam Gazali (2015: 69) menyatakan Mural sebagai lukisan besar yang dibuat untuk mendukung ruang arsitektur. Jadi, dapat disimpulkan bahwa Mural adalah seni lukis yang dibuat diatas media dinding untuk mendukung ruang arsitektur. Dalam perkembangannya seni Mural tidak hanya memiliki nilai keindahan namun juga dapat menjadi media penyampaian nilai-nilai edukatif ditengah-tengah masyarakat. Dengan lokasi yang strategis yaitu sebagai akses lalu lintas dan aktivitas masyarakat dari desa satu ke desa lainnya sehingga menjadi pusat perhatian bagi siapapun yang melintasi pemandian air barat ini. Oleh sebab itu, kami tertarik untuk membuat karya Seni Mural di Pemandian Air Barat Desa Ranggung Sebagai Media Pendukung Berbasis Edukasi Sosial Kemasyarakatan.

\section{METODE PENELITIAN}

Untuk mencapai tujuan yang diharapkan pada program ini, mahasiswa KKN di desa Ranggung melalui berbagai tahapan dan terbagi menjadi beberapa tahap seperti, tahap persiapan, tahap pelaksanaan dan tahap penyelesaian. Pada tahap persiapan mahasiswa melakukan observasi lapangan selama 2 hari yaitu pada hari Rabu dan Kamis pada Tanggal 29-30 Januari 2020, pada tahap pelaksanaan mahasiswa melakukan selama 5 hari terhitung dari tanggal 31 Januari sampai dengan 04 Februari 2020, sedangkan pada tahap penyelesaian dilakukan selama 1 hari pada tanggal 05 Februari 2020.

\section{HASIL DAN PEMBAHASAN}

\section{A. Profil Desa Ranggung}

Desa ranggung berada dalam kecamatan payung kabupaten bangka selatan terbentuk melalui undang-undang No 5 Tahun 2003 tentang pembentukan kabupaten Bangka Selatan, Kabupaten Bangka Tengah, Kabupaten Bangka Barat dan Kabupaten Belitung Timur yang dituangkan dalam lembaran negara republik Indonesia Tahun 2003 No 25, tambahan lembaran negara Rebulik Indonesia No 4268, seiring dengan terbentuknya Kabupaten Bangka Selatan gaung untuk melakukan sebuah perubahan kearah pembangunan juga disambut oleh seluruh anak negeri junjung besaoh terutama masyarakat desa ranggung.
Kabupaten Bangka Selatan terdiri dari 8 Kecamatan. Yakni Kecamatan Toboali, Kecematan Air Gegas, Kecamatan Payung, Kecamatan Simpang Rimbah, Kecamatan Pulau Besar, Kecamatan Tukak Sadai, Kecematan Kepulauan Pongok, dan Kecamatan Lepar. Dimana desa ranggung masuk dalam wilayah Kecamatan Payung.

Sesuai dengan kondisi geografis, desa ranggung beriklim tropis dengan musim yaitu musim kemarau atara bulan april-september dan musim penghujan antara bulan oktobermaret. Sedangkan curah hujan rata-rata 227,9 $\mathrm{mm}$, suhu udara bekisar antara $26^{\circ} \mathrm{C}-27,3^{\circ} \mathrm{C}$ dengan kelembapan udara rata-rata $77,4 \%$ $87,3 \%$.

Ada pun visi Desa Ranggung yakni : “ Terciptanya Masyarakat Desa Ranggung Yang Tentram, Maju, Makmur, Dan Berkeadilan".

\section{B. Pemandian umum}

Pemandian umum adalah fasilitas pemandian publik yang dapat diakses segolongan masyarakat pengguna. Pemandian umum muncul dari kebutuhan masyarakat akan kesehatan, kebersihan, dan sanitasi. Salah satu pemandian umum yang ada di desa Ranggung yaitu Pemandian Umum Air Barat. Pemandian ini terletak di dusun 1 RT 12 Desa Ranggung.

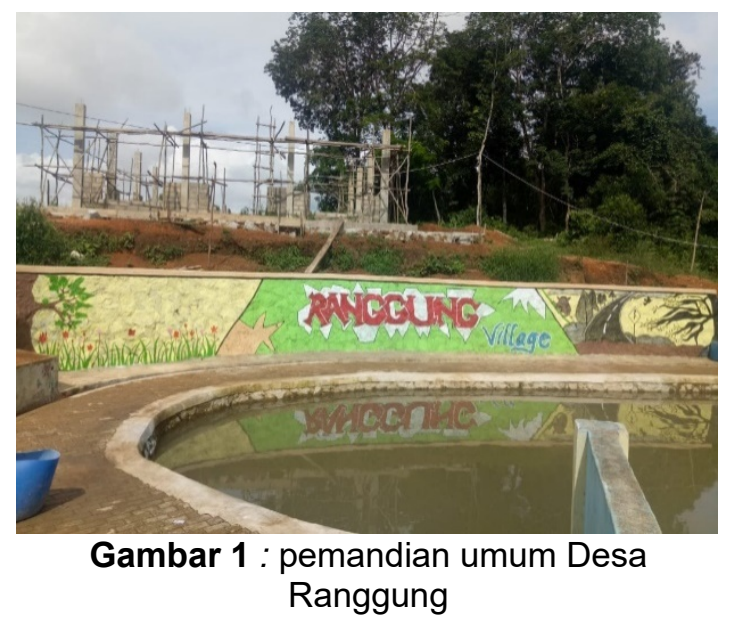

Pemandian ini belum sepenuhnya dikelola oleh pemerintah desa, hal ini terlihat dari situasi yang ada bahkan tempat ini baru saja selesai dan belum sepenuhnya rampung.

\section{Karya Seni Mural}

\section{a. Seni Mural}

Menurut Susanto dalam Suherman, dkk (2019: 197) mendefinisikan mural yang berasal dari kata 'murus' (tembok) sebagai lukisan besar yang dibuat untuk mendukung ruang arsitektur. Lebih lanjut Susanto bahwa, mural merupakan lukisan yang dibuat secara langsung maupun tidak langsung pada permukaan dinding suatu bangunan, yang tidak 
langsung memiliki kesamaan dengan lukisan atau sejenis dengan istilah fresko. Perbedaannya terletak pada persyaratan khusus yang harus dipenuhi oleh lukisan dinding; keterkaitannya dengan arsitektur/bangunan, baik dari segi desain, maupun usia serta perawatan dan juga dari segi kenyamanan pengamatannya.

Menurut Ramadani, Fachmi, dkk (2018: 622) Mural dalam ruang publik sebagai pembawa pesan sosial memcoba mengkritisi apa yang sedang terjadi berupa isu global maupun isu sekitar. Dalam hal aktivitas seniman memanfaatkan perangkat desa sebagai medianya seperti tembok menjadi media alternatif dalam memberikan pesan untuk merespon sebuah fenomena yang terjadi. Pesan dalam mural disampaikan dalam bentuk visual yang sarat akan lambang, tanda, kode dan makna. Cara penyampaian pesan dalam komunikasi visual terdiri dari dua jenis, yaitu secara verbal maupun visual. Gambaran verbal dalam mural adalah bahasa yang berwujud tulisan, sedangkan gambaran visual adalah bentuk dan warna yang disajikan dalam mural tersebut.

Bagi seniman mural, ada pesan-pesan yang ingin disampaikan melalui karyakaryanya. Selain sebagai media ekspresi estetik, mural juga dapat hadir sebagai sebagai media komunikasi, serta dapat juga sebagai representasi atas kondisi-kondisi sosialbudaya, politik, ekonomi dan termasuk pendidikan. Mural sebagai sarana pendidikan di masyarakat, memang disarankan agar para masyarakat ketika melihat lukisan dinding yang dibuat, selain menjadi 'terhibur', sekaligus mendapatkan pesan-pesan dari lukisan dinding atau mural yang dilihatnya. Demikian, karena pembuatan mural di lingkungan masyarakat, memang tidak hanya memikirkan unsur estetiknya saja, melainkan, dan yang paling utama adalah nilai-nilai edukatif yang ingin disampaikan kepada masyarakat melalui mural tersebut. Dengan demikian, boleh dikatakan mural dalam lingkungan masyarakat menjadi penting dan sangat mendidik.

Ada banyak pesan yang ingin dikomunikasikan kepada masyarakat melalui mural dalam lingkungan masyarakat, terutama pesan-pesan akan pentingnya menjunjung tinggi nilai-nilai moral (etika). Sebagai contoh, sebuah lukisan yang menggambarkan orang yang membuang sampah pada tempatnya dan berupa slogan-slogan yang befungsi untuk menghimbau masyarakat agar terhindar dari narkoba dan kewajiban menutup aurat serta dilengkapi dengan beberapa tempat berfoto untuk memperindah sekaligus menarik perhatian masyarakat.
Menurut Ramadani, Fachmi, dkk (2018: 624) Apa yang disebut "Seni" memang merupakan suatu wujud yang terindra. Karya seni merupakan sebuah benda atau artefak yang dapat dilihat, didengar, atau dilihat dan sekaligus didengar (visual, audio, dan audiovisual), seperti lukisan, music, dan teather. Tetapi, yang disebut seni itu berada diluar benda seni sebab seni itu berupa nilai. Apa yang disebut indah, baik, adil, sederhana, dan bahagia itu adalah nilai. Apa yang oleh seseorang disebut indah dapat tidak indah bagi orang lain. Nilai itu sifatnya subjektif. Yaitu berupa tanggapan individu terhadap sesuatu (disini, benda seni / objek seni) berdasarkan pengalaman dan pengetahuannya. Tanggapan individu terhadap sesuatu benda seni akan membangkitkan kualitas nilai tertentu sesuai denga nilai-nilai seni dikenal dan dialami individu. Menurut Clive Bell seorang filsuf seni "klasik modern", seni merupakan semua sistem estetik dimulai dari pengalaman pribadi subjek tentang terjadinya emosi yang khas. Kalau seseorang menatap sebuah karya seni (Bell hanya mau berbicara tentang seni lukis) dalam dirinya akan timbul suatu perasaan/ emosi yang khas, yang tidak sama dengan perasaan sehari-hari kita seperti marah, sedih, gembira, mulia, dll. Perasaan spesifik atau khas tadi disebut emosi estetik. Setiap emosi estetik tertentu berbeda satu sama lain. Tetapi, berbagai emosi estetik yang berbeda-beda tadi saling memiliki kesamaan dalam karakteristiknya.

\section{b. Mural}

Menurut Ramadani, Fachmi, dkk (2018: 624) Mural adalah gambar atau lukisan pada dinding, langit- langit ruang, atau tempat permanen dengan ukuran yang besar. Menurut Susanto memberikan definisi mural sebagai lukisan besar yang dibuat untuk mendukung ruang arsitektur. Definisi tersebut bila diterjemahkan lebih lanjut, mengartikan bahwa mural sebenarnya tidak dapat dilepaskan dari bangunan, dalam hal ini dinding. Dinding dipandang tidak hanya sebagai pembatas ruang maupun sekadar unsur yang harus ada dalam bangunan rumah atau gedung, namun dinding juga dipandang sebagai medium untuk memperindah ruangan. Kesan melengkapi arsitektur dapat dilihat pada bangunan gereja Katolik yang bercorak Barok yang terpampang pada atap gereja, biasanya berupa kubah dengan lukisan awan dan cerita-cerita di Alkitab. Mural juga berarti lukisan yang dibuat langsung maupun tidak langsung pada permukaan dinding suatu bangunan, yang tidak langsung memiliki kesamaan dengan lukisan. Perbedaannya terletak pada persyaratan khusus yang harus dipenuhi oleh lukisan 
dinding, yaitu keterkaitannya denganarsitektur/bangunan, baik dari segi desain (yang memenuhi unsur estetika), maupun usia serta perawatan dan juga dari segi kenyamanan pengamatannya. Mural dan graffiti dibedakan berdasarkan objeknya, graffiti lebih menekankan pada stilisasi rangkaian huruf dan biasanya dikerjakan dengan cat semprot (airbrush), sering disebut "spray-can art", sedangkan mural lebih menekankan pada kemampuan drawing (menggambar objek). Fresco adalah teknik membuat lukisan dinding dengan mengoleskan warna pada dinding dengan mengoleskan waena pada plester yang masih basah atau mencampurkan warna dengan semen pelapis dinding. Teknik ini membutuhkan ketelitian tinggi, kecepatan dan tenaga kerja yang relatif banyak, terutama karena berpacu dengan waktu sebelum polesan plester dinding mengering. Mural dengan teknik fresco biasanya tahan lama dan warnanya terjaga meskipun telah berusia ribuan tahun.

\section{c. Fungsi Mural Pada Umumnya}

Menurut Ramadani, Fachmi, dkk (2018: 625-626) Fungsi Mural Ribuan makna. Bagi pembuatnya, ada pesan-pesan yang ingin disampaikan melalui mural. Terdapat pesan dengan memanfaatkan kehadiran mural dengan mencitrakan kondisi di sekelilingnya, di antaranya mural hanya untuk kepentingan estetik, untuk menyuarakan kondisi sosial budaya, ekonomi dan juga politik. a. Sosial budaya Hubungan sosial tergambarkan dengan ada relasi yang cukup erat antara gambar dalam mural dengan kondisinya dalam segi kesehatan, kepercayaan, pendidikan, nilai kebudayaan, dan norma b. Estetik Mural dengan kepentingan estetik seringkali dilakukan untuk kebutuhan desain interior/dalam ruangan, misalnya untuk menampilkan kesan segar maupun kesan berada dalam alam yang penuh dengan suasana hijau nan sejuk, untuk menimbulkan kenyamanan dari sang pemilik rumah maupun ruangan, namun mural dengan tampilan estetik sebagai pokok utamanya juga dapat dilakukan di luar ruang/eksterior. Mural seperti ini biasanya merepresentasikan dari gaya visual, seperti komik, simbolik, ekspresionisme hingga realism. c. Ekonomi Pesan dalam mural yang menyuarakan pentingnya ekonomi untuk kemajuan bersama. hal ini bisa kita lihat belakangan ini,perusahaan-perusahaan besar memanfaatkan seni mural sebagai media promosi dalam memasarkan produknya. fenomena beriklan melalui media mural juga telah banyak. Memanfaatkan momentum dan julukan yang melekat erat, belum lagi perusahaan telekomunikasi seperti Telkom Flexi dan Indosat bersaing memanfaatkan momentum di Jogja perihal mural. Tentu saja hal ini meningkatkan nilai perekonomian daerah setempat, meskipun mural yang seperti ini berdampak kuat,namun juga sering menimbulkan nilai negatif dalam setiap penerapanya. karena dikhawatirkan pemakaian media muralsebagai media iklan semakin menambah polusi visual seperti halnya billboard. Dinding yang dipakai biasanya dinding yang menghadap ke jalan raya, padat kendaraan dan rumah yang berlantai dua. $d$. Politik Mural dengan pesan sponsor dari partai politik biasanya menjamur ketika musim Pemilu tiba. Hal ini tentu bertolak belakang bila melihat mural yang dibuat oleh negara-negara sosialis maupun negara yang sedang berkecamuk. Mural bagi negara-negara tersebut menyuarakan pada kepatuhan terhadap ideologi yang dianut, dukungan kepada pemerintah hingga ajakan untuk melawan pemerintah. Kuba sebagai sebuah negara sosialis mural mudah ditemui di jalan-jalan utama sebagai bentuk penyanjungan kepada penguasa maupun pahlawan-pahlawan mereka.

\section{Unsur-Unsur Pembentuk Rupa dan Prinsip-Prinsip Desain Dalam Mural}

1. Menurut Chandra (2013: 44) UnsurUnsur Pembentuk Rupa dalam Mural yakni Unsur-unsur pembentuk rupa/elemen seni yang terdapat dalam mural terdiri dari garis/line, bentuk/form, bidang/shape, warna/colour, huruf/kalimat (tipografi) dan ruang/space. Unsur pembentuk rupa tersebut diorganisasi dengan mempertimbangkan pada prinsip-prinsip penciptaan karya seni (prinsip-prinsip desain) sehingga terbentuklah lukisan mural. Unsur-unsur pembentuk rupa tersebut akan dijelaskan sebagai berikut:

a. Garis (line)

Garis merupakan salah satu unsur visual dalam karya seni lukis dan merupakan elemen pokok dalam seni rupa.Di samping potensi garis sebagai pembentuk kontur, di dalam mural garis merupakan elemen untuk mengungkapkan gerak dan bentuk. Baik bentuk dua dimensi maupun yang berkesan tiga dimensi. Aspek garis dalam mural bermacam-macam, di antaranya berdasarkan jenis yaitu lengkung, zig-zag, dan bergelombang. Berdasarkan wujud atau ukuran, terdapat garis panjang pendek, besar kecil dan tebal tipis. Berdasarkan arahnya, terdapat garis vertikal, diagonal, horisontal dan radial. Berdasarkan sifatnya garis terbagi menjadi garis positif dan garis negatif, garis positif merupakan garis yang 
sengaja dibentuk, sedangkan garis negatif terjadi karena singgungan dari dua bidang atau warna yang berlainan.

b. Bentuk (form) dan bidang (shape)

Bentuk (form) dan bidang (shape) Bentuk/form dilihat sebagai 3 (tiga) dimensi dan merupakan total struktur karya seni. Sedangkan bangun/shape merupakan berdimensi 2 (dua) dan merupakan pecahan/unsur kecil dari keseluruhan bentuk (Sahman, 1993:41). Sebuah garis yang bertemu dan saling berpotongan antara satu sama lain akan membentuk beberapa bidang/shape, seperti halnya garis, bidang ataupun unsur bidang juga menyatakan sifat atau watak yang berbeda-beda. Berdasarkan sifat-sifatnya, maka bidang rata yang lebar memberi kesan lapang, bidang rata yang mendatar mengesankan unsur lantai yang membentang. Bidang rata yang tegak mengesankan seperti dinding pembatas, sedangkan bidang bergelombang tegak menimbulkan kesan menyempit pada ruang yang dibatasinya.

Pada proses berkarya seni, bentuk menempati posisi yang tidak kalah penting dibanding elemen-elemen lainnya, mengingat bentuk-bentuk geometris biasanya merupakan simbol yang membawa nilai emosional tertentu. Hal tersebut biasa dipahami, karena pada bentuk atau rupa mempunyai image. Dalam mural dapat diterapkan bentuk dua dimensi atai tiga dimensi, maupun kombinasi keduanya pada semua objek. Penerapan bayangan dan perspektif pada lukisan tiga dimensi biasa disebut trompe l'oil, memberi ilusi visual (memanipulasi space). Misalnya lukisan bingkai jendela dan pemandangan taman pada dinding akan berbeda pada wujud jendela sesungguhnya, namun berhasil memberi image yang meningkatkan kualitas ruang.

c. Warna (colour)

Warna (colour) Menurut Poerwadaminta dalam Kamus Besar Bahasa Indonesia (1997:1269) dijelaskan bahwa warna adalah kesan yang diperoleh mata dari cahaya oleh benda-benda yang dikenainya. Wong (1989:4) menyebutkan bahwa; selain tampak visual, warna dapat membedakan bentuk sekelilingnya, warna di sini tidak hanya spektrum saja tetapi juga mencakup warna netral (hitam dan putih). Menurut B.S. Myers dalam Sahman (1993:64), mengemukakan bahwa dari segi manapun seseorang menelaah tentang warna dalam kaitannya dengan seni visual, maka akan dilihat dengan jelas perannya yang sangat esensial. Peranan tersebut antara lain untuk menyatakan gerak, jarak, tegangan/tension, deskripsi alam/naturalisme, ruang, bentuk, ekspresi (makna) simbolik Di dalam pengetahuan mural, warna merupakan unsur keindahan di samping unsur-unsur lainnya. Warna juga mempunyai nilai estetis dan mampu mewakili pesan dari karya seni.

Di samping itu warna juga mempunyai nilai psokologis, karena tanggapan setiap orang terhadap warna berbeda-beda, kesan seseorang terhadap warna sangat tergantung pada kondisi perasaan dan kepekaannya. Setiap pelukis biasanya mempunyai ciri khas di dalam penggunaan warna untuk menciptakan karyanya sesuai dengan kepribadiannya masing-masing, selain itu kesesuaian dengan pesan yang akan disampaikan juga menjadi pertimbangan penting dalam pemilihan warnanya (Bustami, 1992:62). Sebagai bagian dari unsur pembentuk rupa, warna memegang peran sebagai sarana untuk lebih mempertegas dan memperkuat karakter pesan dalam karya seni.

Dalam proses penuangan gagasan seniman ke dalam medium, warna mempunyai fungsi untuk memperkuat aspek identitas. Lebih lanjut dikatakan oleh Henry Dreyfuss dalam logo.resource.com, warna dapat digunakan dalam mempertegas maksud dari simbol-simbol. Sebagai contoh adalah penggunaan warna merah pada segitiga pengaman, warna-warna yang digunakan dalam traffic light merah untuk berhenti, kuning untuk bersiap-siap dan hijau untuk jalan, sehingga di dalamnya terdapat arti benda yang konotatif. Dari contoh tersebut ternyata pengaruh warna mampu memberikan impresi yang cepat dan kuat. Kemanapun warna menciptakan impresi, mampu menimbulkan efek-efek tertentu. potensi karakter warna yang mampu memberikan kesan pada seseorang sebagai berikut: Hitam, sebagai warna yang tertua (gelap) dengan sendirinya menjadi lambang untuk sifat gulita dan kegelapan (juga dalam hal emosi). 2) Putih, sebagai warna yang paling terang, melambangkan cahaya, kesulitan. 3) 
Abu-abu, merupakan warna yang paling netral dengan tidak adanya sifat atau kehidupan spesifik. 4) Merah, bersifat menaklukkan, ekspansif (meluas), dominan (berkuasa), aktif dan vital (hidup). 5) Kuning, dengan sinarnya yang bersifat kurang dalam, merupakan wakil dari hal-hal atau benda yang bersifat cahaya, momentum, dan mengesankan sesuatu. 6) Biru, sebagai warna yang menimbulkan kesan dalamnya sesuatu (dediepte), sifat yang tak terhingga dan transenden, di samping itu memiliki sifat tantangan. 7) Hijau, mempunyai sifat keseimbangan dan selaras, membangkitkan ketenangan dan tempat mengumpulkan daya-daya baru. Dari pemahaman di atas dapat dijelaskan bahwa warna selain hanya dapat dilihat dengan mata, ternyata mampu mempengaruhi perilaku seseorang dan juga mempengaruhi penilaian estetis terhadap suatu karya seni.

d. Huruf (text/tipografi)

Dalam mural terdapat juga unsur pembentuk rupa, yaitu huruf yang disusun membentuk kata /kalimat, huruf di sini sebagai tanda visual dan tanda verbal dalam mural. Telah dijelaskan bahwa perbedaan antara mural dan graffiti dilihat berdasarkan objeknya. Graffiti lebih menekankan pada stilisasi rangkaian huruf dan biasanya dikerjakan dengan teknik cat semprot/airbrush, sedangkan mural lebih menekankan pada kemampuan drawing (menggambar objek). Dalam mural kadang juga terdapat huruf/teks yang berfungsi sebagai aksen dari keseluruhan komposisi unsur-unsur pembentuk rupa yang lain dan sekaligus sebagai penjelas dari pesan yang disampaikan seniman. Penyusunan huruf sering disebut sebagai tipografi yang merupakan seni memilih dan menata huruf dengan pengaturan penyebarannya pada ruang-ruang yang tersedia, untuk menciptakan kesan khusus sehingga akan menolong pembaca untuk mendapatkan kenyamanan membaca semaksimal mungkin. Dengan berbagai karakternya, seniman memilih bentuk-bentuk huruf sebagai penegas pesan dalam mural. Dalam pemilihan jenis huruf yang harus diperhatikan adalah penonjolan tema tersebut, sehingga terjadi korespondensi antara gambar dan huruf. e. Ruang (space)

Ruang adalah pemanfaatan value/nilai dan pemanfaatan bayangan pada objek lukisan. Ruang menurut Susanto (2002:99); "Ruang dikaitkan dengan bidang dan keluasan, yang kemudian muncul istilah dwimatra dan trimatra. Dalam seni rupa, orang sering mengkaitkannya dengan bidang yang memiliki batas atau limit, walaupun kadang-kadang bersifat tidak terbatas dan tidak terjamah. Ruang juga dapat diartikan secara fisik adalah rongga yang terbatas maupun tidak terbatas oleh bidang. Sehingga pada suatu waktu, dalam hal berkarya seni, ruang tidak lagi dianggap memiliki batas secara fisik, contohnya pada karya-karya seni lingkungan (environmental art), happening art, dan lain-lain. Dalam seni lukis, ruang dalam perkembangannya terkait dengan konsep, contohnya zaman Renaissance dengan perspektif digunakan untuk menghasilkan ilusi susunan kedalaman tertentu atau di Cina, lebih menghargai arti ruang kosong sebagai makna filosofis, dengan kekosongan jiwa dapat diwujudkan kemungkinan-kemungkinan yang lain." bidang keluasan dalam dua atau tiga dimensional (volume). Unsur seni lukis ini digunakan untuk menimbulkan kesan kedalaman dari objek yang dilukiskan. Kesan ini dapat dilalui dengan gradasi warna terang ke warna gelap, begitu pula sebaliknya. Kesan ini juga bisa ditimbulkan dengan Ruang dalam Kamus Besar Bahasa Indonesia berarti sela-sela antara dua deret tiang atau antara empat tiang, rongga atau terlingkung oleh bidang, rongga yang tidak terbatas tempat segala yang ada. Sejalan dengan pengertian di atas dapat diambil pengertiannya, ruang adalah rongga atau keluasan dari suatu bidang atau permukaan, baik itu dua atau tiga dimensi, baik dibatasi oleh limit atau tidak terbatas dan tak terjamah, kesan itu diperoleh melalui image/gambaran batas bidang yang nyata.

\section{E. Nilai Edukasi}

Menurut Ramadani, Fachmi, dkk (2018:

623) Secara umum, nilai berkaitan dengan kemerdekaan seseorang dalam bertindak. Nilai membantu individu untuk mengarahkan dalam bertindak berdasarkan pilihan-pilihan yang dibuat secara sadar. Nilai merupakan dasar pertimbangan seseorang dalam memilih dan juga menentukan sikap serta mengambil keputusan atau suatu hal. Nilai menetukan 
peringkat prioritas dari berbagai alternative tingkah laku yang mungkin dilakukan seseorang. Setiap individu menyakini bahwa nilai yang dimiliki oleh masyarakat. Sebuah nilai diakui apabila tidak bertentangan dengan nilainilai lain yang ada dimasyarakatdan juga bersifat abstrak. Arti dari kata abstrak adalah bersifat umum, memiliki ruang lingkup yang luas dan umumnya sulit dijelaskan secara rasional dan juga nyata.

\section{Pengertian Nilai Edukasi}

Menurut Soelaeman dalam Endang Susilowati (2013: 28) mengatakan bahwa nilai adalah sesuatu yang dipentingkan manusia sebagai subjek, menyangkut segala sesuatu yang baik atau yang buruk, sebagai abstraksi, pandangan atau maksud dari berbagai pengalaman dalam seleksi perilaku yang ketat.

Menurut Purwanto masih dalam Endang Susilowati (2013: 30) menyatakan bahwa pendidikan (Edukasi) berarti segala usaha orang dewasa dalam pergaulannya dengan anak-anak untuk memimpin perkembangan jasmani dan rohaninya ke arah kedewasaan. Hakikat pendidikan bertujuan untuk mendewasakan anak didik, maka seorang pendidik haruslah orang yang dewasa, karena tidak mungkin dapat mendewasakan anak didik jika pendidiknya sendiri belum dewasa.

Berdasarkan dari beberapa pendapat diatas dapat disimpulkan bahwa nilai edukasi (pendidikan) adalah batasan segala sesuatu yang mendidik ke arah kedewasaan, bersifat baik maupun buruk sehingga berguna bagi kehidupannya yang diperoleh melalui proses pendidikan.

\section{Macam-macam Nilai Edukasi}

Adapun macam-macam nilai pendidikan menurut Wardani masih dalam Endang Susilowati (2013: 31) yaitu sebagai berikut:

\section{a. Nilai Edukasi Religius}

Religi merupakan suatu kesadaran yang menggejala secara mendalam dalam lubuk hati manusia sebagai human nature. Religi tidak hanya menyangkut segi kehidupan secara lahiriah melainkan juga menyangkut keseluruhan diri pribadi manusia secara total dalam integrasinya hubungan ke dalam keesaan Tuhan. Nilai-nilai religius bertujuan untuk mendidik agar manusia lebih baik menurut tuntunan agama dan selalu ingat kepada Tuhan. Nilai-nilai religius yang terkandung dalam karya seni dimaksudkan agar penikmat karya tersebut mendapatkan renungan-renungan batin dalam kehidupan yang bersumber pada nilai-nilai agama. Nilai- nilai religius dalam seni bersifat individual dan personal.

Dalam hal ini pembuatan Mural yang kami buat yaitu dengan kata-kata yang berkaitan dengan ajakan untuk menutup aurat bagi perempuan dengan kata-kata "tutupi auratmu, seperti engkau menutupi aibmu"

Gambar 2 :Mural yang berisi nilai-nilai

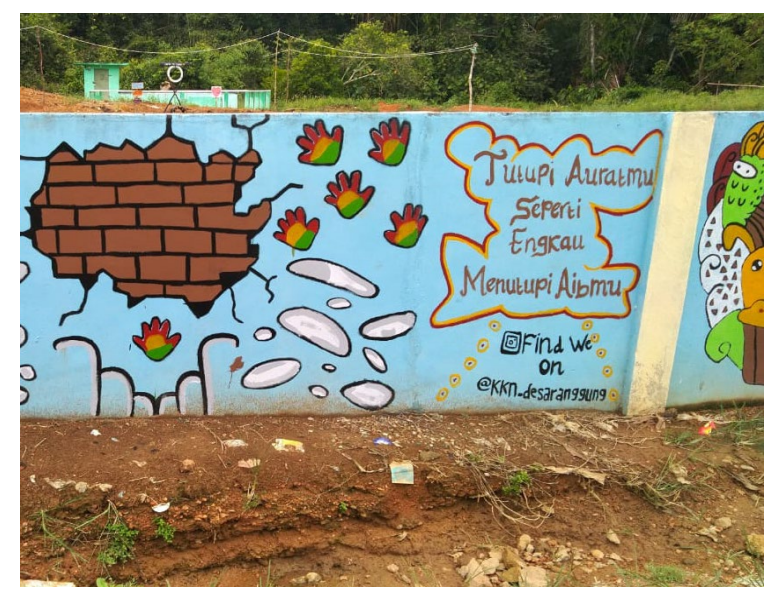

keagamaan

\section{b. Nilai Edukasi Moral}

Moral merupakan makna yang terkandung dalam karya seni, yang disaratkan lewat cerita. Moral dapat dipandang sebagai tema dalam bentuk yang sederhana, tetapi tidak semua tema merupakan moral menyatakan bahwa, moral merupakan kemampuan seseorang membedakan antara yang baik dan yang buruk. Nilai moral yang terkandung dalam karya seni bertujuan untuk mendidik manusia agar mengenal nilai-nilai etika merupakan nilai baik buruk suatu perbuatan, apa yang harus dihindari, dan apa yang harus dikerjakan, sehingga tercipta suatu tatanan hubungan manusia dalam masyarakat yang dianggap baik, serasi dan bermanfaat bagi orang itu, masyarakat, lingkungan dan alam sekitar.

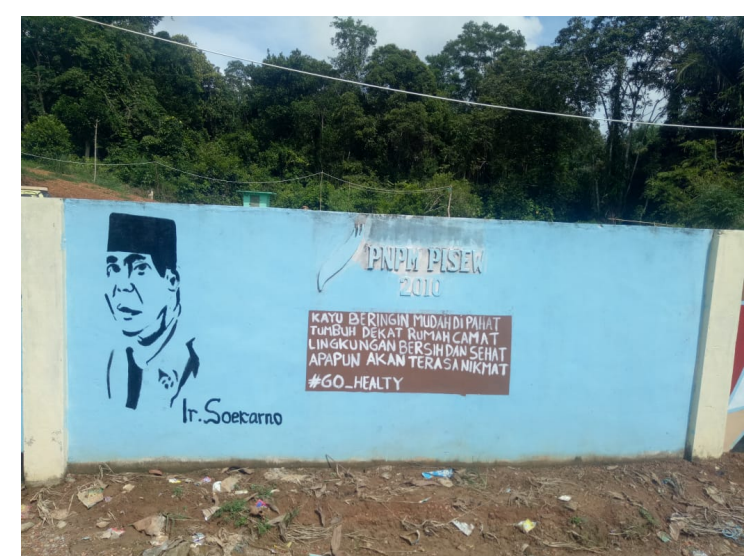

Gambar 3 :Mural yang berisi kalimat ajakan menjaga lingkungan 
Pembuatan mural dalam menerapkan nilai-nilai edukasi atau pendidikan dibuat seprti pantun yaitu: kayu beringin midah dipahat, tumbuh dekat rumah camat, lingkungan bersih dan sehat, apapun akan terasa nikmat. Arti dari tulisan tersebut bahwa kita harus selalu menjaga kebersihan rumah kita supaya terasa nyaman, asri, tentram dan damai.

\section{c. Nilai Edukasi Sosial}

Kata "sosial" berarti hal-hal yang berkenaan dengan masyarakat/ kepentingan umum. Nilai pendidikan sosial merupakan hikmah yang dapat diambil dari perilaku sosial dan tata cara hidup sosial. Perilaku sosial berupa sikap seseorang terhadap peristiwa yang terjadi di sekitarnya yang ada hubungannya dengan orang lain, cara berpikir dan hubungan sosial bermasyarakat antar individu. Nilai pendidikan sosial yang ada dalam karya seni dapat dilihat dari cerminan kehidupan masyarakat yang diinterpretasikan. Nilai pendidikan sosial akan menjadikan manusia sadar akan pentingnya kehidupan berkelompok dalam ikatan kekeluargaan antara satu individu dengan individu lainnya.

Dalam mural edukasi sosial, kami menerapkan tulisan dengan kata-kata ajakan untuk menjauhi narkoba agar kita hidup sehat dan tidak melupakan agama sebagai pondasi utama kita.

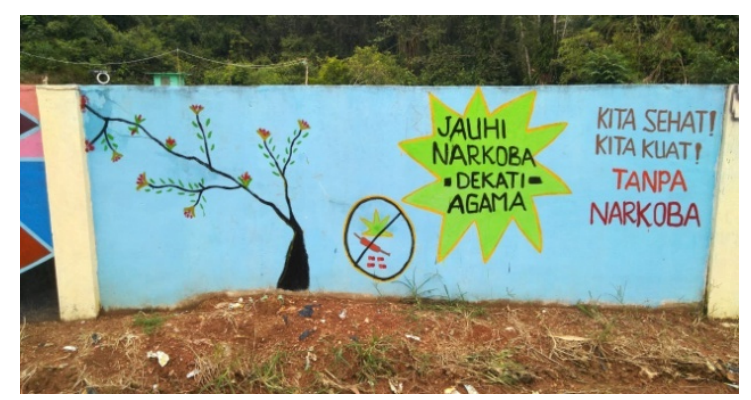

Gambar 4: Mural Nilai Edukasi Sosial

\section{d. Nilai Edukasi Budaya}

Nilai-nilai budaya merupakan sesuatu yang dianggap baik dan berharga oleh suatu kelompok masyarakat atau suku bangsa yang belum tentu dipandang baik pula oleh kelompok masyarakat atau suku bangsa lain sebab nilai budaya membatasi dan memberikan karakteristik pada suatu masyarakat dan kebudayaannya. Nilai budaya merupakan tingkat yang paling abstrak dari adat, hidup dan berakar dalam alam pikiran masyarakat, dan sukar diganti dengan nilai budaya lain dalam waktu singkat.

Pada penerapan edukasi budaya kami menerapkan agar selalu melakukan budaya kebersihan agar selalu hidup sehat, dan selain kata-kata, kami juga membuatkan objek dengan gambaran hitam anak-anak yang membuang sampah pada tempatnya.

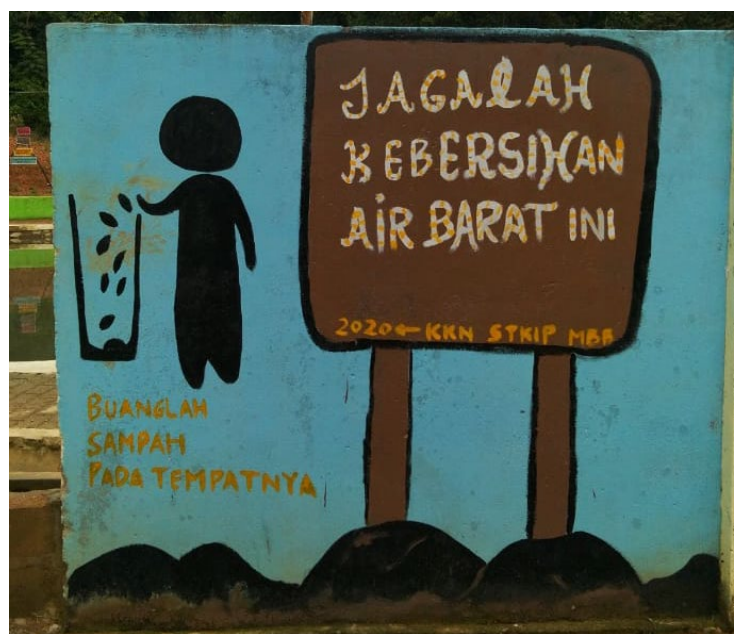

Gambar 5: Mural dengan nilai-nilai edukasi sosial

\section{SIMPULAN DAN SARAN}

Berdasarkan hasil pembahasan diatas dapat disimpulkan bahwa program KKN di Desa Ranggung adalah salah satu bentuk pengabdian dari mahasiswa untuk masyarakat dari program yang telah dilaksanakan salah satunya pembuatan mural di Air Barat. Mural dalam ruang publik sebagai pembawa pesan sosial memcoba mengkritisi apa yang sedang terjadi berupa isu global maupun isu sekitar. Dalam hal aktivitas seniman memanfaatkan perangkat desa sebagai medianya seperti tembok menjadi media alternatif dalam memberikan pesan untuk merespon sebuah fenomena yang terjadi. Pesan dalam mural disampaikan dalam bentuk visual yang sarat akan lambang, tanda, kode dan makna. Cara penyampaian pesan dalam komunikasi visual terdiri dari dua jenis, yaitu secara verbal maupun visual. Gambaran verbal dalam mural adalah bahasa yang berwujud tulisan, sedangkan gambaran visual adalah bentuk dan warna yang disajikan dalam mural tersebut. Selain itu mahasiswa KKN STKIP Muhammadiyah Bangka Belitung juga berharap dengan pembuatan mural disana juga bisa bermafaat dan juga bertujuan untuk memberikan pesan moral kepada masyarakat meliputi nilai keagamaan, nilai sosial, dan nilai budaya.

\section{DAFTAR RUJUKAN}

Cristian Oki Candra. (2013). Pesan Visual Mural Kota Karya Jogja Mural Forum Yogyakarta. Universitas Negeri Yogyakarta. 
Endriawan, Didit. (2017). Mural Sebagai Media Pendidikan dan Pengabdian Masyarakat. Surabaya: UNESA

Fachmi, Ramadani. Dkk. (2018). Pesan Sosial Dalam Seni Mural Di Kota Samarinda. eJournal Ilmu Komunikasi. 1 (3).

Matnur, dkk. (2019). Profil Desa Ranggung.

Gazali, Muhammad. (2017). Seni Mural Ruang Publik Dalam Konteks Konservasi. Semarang: UNNES.

Susilowati, Endang. (2013). Nilai-nilai Edukasi Dalam Iklan Televisi (Analisis Semiotika Roland Barthes Pada Iklan Nutrilon Royal 3-Life Is An Adventure). Surabaya: IAIN Sunan Ampel.

Suherman, dkk. (2019). Mural Di Lingkungan Sekolah Dalam Konteks Pendidikan Konservasi Refleksi Edukatika. Kudus: Universitas Muria Kudus. 